time branches and 30,144 part-time branches, centres, etc., as well as 185 mobile libraries.

\section{Scientific Bibliography for the Middle East}

TrE National Research Council of Egypt, Cairo, is issuing, as a continuation of the "List of Scientific Pupers published in the Middle East", abstracts of scientific and technical papers published in Egypt and papers received from Afghanistan, Cyprus, Iran, Iraq, Lebenon, Pakistan, Sudan and Syria, of which Nos. 3 and 4, Vol. 1 (October and December 1955), have already appeared. The abstracts are classified under pure and applied mathematics; astronomy and geophysics; physics; pure and applied chemistry; geological sciences; biological sciences; medical sciences; engineering; agriculture and veterinary sciences, with sub-divisions as required; and there are author and subject indexes. The first four issues have been distributed free for publicity purposes, but beginning with No. 1, Vol. 2 (January 1956), the Bulletin is being published monthly and distributed regularly only by subscription or in exchange for other scientific publications. Applications should be made to the Director of the Scientific and Technical Documentation Centre, National Research Council of Egypt, Dokki, Cairo.

\section{London Computer Group : Regional Centres}

THe London Computer Group has now completed arrangements to assist in the formation of other similar groups of members outside the London area. These groups will share common services, but retain their local autonomy and individuality. The regional centres are intended to fulfil the same objects as the London Computer Group-the creation of opportunities for specialists in many fields, with some interest in the design, manufacture and use of electronic computers and data processing equipment, to meet together, as individuals and not at an official level, for the discussion of common problems and the exchange of knowledge and experience. Further details may be obtained from the Hon. Secretaries to the Group at 29 Bury Street, St. James's, London, S.W.1.

The London Computer Group is also setting up a Research Sub-Committee to report on specific problems addressed to it from time to time, and in particular to maintain the annual survey of com. puters and electronic data processing installations operating and planned in Britain.

\section{Veterinary Science in Australia}

The wide scope of modem veterinary science, its relations with agriculture on one hand and with medicine on the other, the opportunities it offers to young men and its achievements in Australia in spite of continuing shortage of veterinarians in that country, were all discussed by Prof. John Francis, dean of the Faculty of Veterinary Science of the University of Queensland, in a recent address given at the ceremony of conferring degrees at that University. Australia has only 800 veterinarians, while Great Britain has 6,000; and Queensland's most valuable animals, sheep and beef cattle, lack almost completely the kind of veterinary services available elsewhere. The Veterinary School in Queensland is, as Prof. Francis explained, doing all it can to remedy this state of affairs. Dr. G. R. Moule, director of the sheep and wool branch of the Division of Animal Industry, who has done distinguished work in this field, is the first person on whom the University of Queensland has conferred the degree of doctor of veterinary science.

Colonel Lionel Rose, chief veterinary officer of the Northern Territory, has rendered valuable service to the cattle industry of that area. Many of the worst animal diseases have been eradicated, and problems of nutrition and animal management have been energetically studied. A great deal, however, remains to be done, and the Veterinary School of the University of Queensland is energetically tackling the problem of the shortage of veterinarians. Prof. Francis outlined the courses of training given, the achievements of the graduates of the School and the development of the University's Farm at Moggill, situated on land given by Dr. Maine and helped by grants from Australian banks and by Mrs. S. M.'Thomson of Worthing; a new veterinary school at St. Lucia is also being built about four miles from the farm.

\section{The Australian Museum}

To promote more interest in its Magazine, the Australian Museum has decided to seek more articles from outside contributors, to include articles on plant life and to publish each December an issue dealing authoritatively with a special topic. For the first special issue the subject is "Australia" (12, No. 4; December 15, 1956). Among the articles is one by Charles F. Laseron describing the nine different geological periods when the sea covered some part of Australia. Winifred M. Curtis describes the flowering plants of Australia, special attention being paid to such peculiar Australian species as Eucalyptus, sheosks (Casuarina sp.), Hakea, Bantisia and the waratah, Telopea. Another article deals with Au'stralian mammals and is illustrated with some remarkable photographs of young bandicoots feeding. The well-known Australian birds, the lyre-bird, bowerbird, kooka-burra, emu and cassowary are described and illustrated, as are more typical Australian insects. The Great Barrier Reef and its corals, by W. Stephenson, forms one of the most interesting articles in the journal.

\section{The South African Museum}

IN the one hundred and first annual report of the South African Museum for the year ending March 31, 1956 (Cape Town: South African Museum, 1956), the Trustees recall with pride the history of that institution which from small beginnings has grown into a scientific organization of international repute. The centenary was celebrated by the unveiling of a memorial plaque by Mr. J. H. Viljoen, Minister of Education, Arts and Science, and a special display illustrating the growth of the Museum and the scope of its activities. Under a new Act of 1954 which repeals the South African Museum Act of 1857, a new Board of Trustees has been appointed. The Trustees consider that the change from a simple trust autonomy to a more complex administration has been accomplished without undue inconvenience but admit that the increase in clerical work threatens to curtail the Director's time for research and scientific work. In the galleries considerable progress has been made with the construction of a new series of dioramas showing present-day reptiles and amphibians.

\section{International Implications of Nuclear Power}

As article, "Atomic Power", by the technical editor of the "International Year Book and States- 